\title{
On the recent floods in India
}

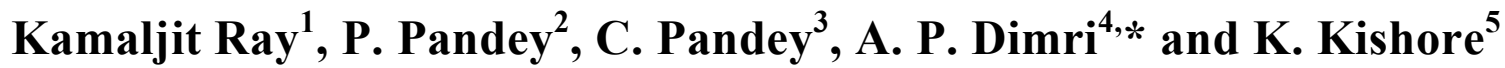 \\ ${ }^{1}$ India Meteorological Department, New Delhi 110 003, India \\ ${ }^{2}$ CSIR-National Geophysical Research Institute, Hyderabad 500 007, India \\ ${ }^{3}$ Wadia Institute of Himalayan Geology, Dehradun 248 001, India \\ ${ }^{4}$ School of Environmental Sciences, Jawaharlal Nehru University, New Delhi 110 067, India \\ ${ }^{5}$ National Disaster Management Agency, New Delhi 110 029, India
}

Floods in the Indian subcontinent have affected habitat, population, economy, etc. Due to the detrimental effects of recent floods on the economy, governance, etc., it is imperative to understand the associated dynamics, manifestations and fallouts for proper policy planning recommendations. The present study endeavours to provide an integrated rationale of meteorological and geomorphological aspects associated with four recent extreme floods in Uttarakhand (2013), Srinagar (2014), Chennai (2015) and Gujarat (2017). It is important to mention here that these floods occurred under different atmospheric circulations and geomorphological setting, and had an entirely different gambit for policy planning and governance. Consolidation of these issues will help policy planners and technologists, in case advance warning system based on these findings can be developed.

Keywords: Advance warning system, disaster management, floods, governance, policy planning.

RAINFALL extremes cause flooding ${ }^{1}$. Increased surface run-off, and precipitation higher than the capacity of outgoing discharge cause the water level to rise, leading to submergence of regions, debris flows/landslides, water-borne health disasters, etc. ${ }^{2}$ and posing threats to sustainable development ${ }^{3}$. Floods impact the ecosystem and society by destroying habitats, affecting lives, damaging infrastructure, etc. Nearly $40 \mathrm{~m}$ ha area in India is flood-prone and every year nearly $8 \mathrm{~m}$ ha of land is affected by floods. Apart from these, floods during rabi and kharif seasons affect food security of the nation. Due to warming climate, increased frequency of rainfall extremes is reported in India ${ }^{4}$. In addition, in recent decades, warming trend over the Indian Ocean ${ }^{5}$ has potentially enhanced moisture supply leading to rainfall extremes in the country ${ }^{6}$. Abrupt variability and increased uncertainties of rainfall patterns, periods, days, amount and risk of weather extremes - as an impact of global climate change-aggravated by ecological and anthropogenic factors, pose ever-increasing risk of flood disaster ${ }^{7}$. However, increased atmospheric water vapour, though

\footnotetext{
*For correspondence. (e-mail: apdimri@hotmail.com)
}

favourable for intense rainfall events, by itself is not sufficient to produce rainfall. Favourable thermodynamic/ dynamic conditions and rising motion in the atmosphere are necessary for rainfall ${ }^{8}$.

Geomorphological settings along with rainfall extremes have led to flooding. In-flow and out-flow limits of sewerage also contribute to flooding. Inundation of a geomorphic substrate by flooding follows a definite pattern. Any infringement to the natural flow path of a river has a disastrous effect on the habitants.

In this article, we briefly discuss the unique geomorphic set-up of three major recent flood-affected regions of India: (i) June 2013 Uttarakhand flood in Upper Ganga valley, (ii) September 2014 Kashmir flood in Jhelum river and (iii) December 2015 Chennai flood. Geomorphic limitations of the terrain in different geological settings causing similar disaster in response to analogous weather phenomenon are highlighted. In addition, Gujarat (2017) flood is discussed in brief, which occurred only with atmospheric forcings. Mechanisms and forcings behind the occurrence of these floods are analysed. This combined analysis may help the policy planners to suggest proper recommendations.

\section{Floods in association with Indian summer monsoon}

The onset of the Indian Summer Monsoon (ISM) and its advance bring rain over different parts of India. ISM has inter-annual and intra-seasonal phases as onset and advance (mid-May to mid-July), peak rainfall (July to August) and withdrawal (mid-September to mid-October). In addition, latent heat source shifts over northern India due to shifting of Intertropical Convergence Zone (ITCZ), which generally stays between $20^{\circ}$ and $30^{\circ} \mathrm{N}$ during the peak monsoon (July-August). The onset and advance phase is often accompanied by one or more transient disturbances. Their movements not only advance the monsoon isochrones to different parts of India, but are accompanied by heavy rainfall in the vicinity of monsoon transients during this phase. Heavy to very heavy monsoon rainfall is normally associated with vigorous monsoon conditions, low pressure systems and monsoon breaks $^{9}$. In the region of the Himalaya, occasionally low 


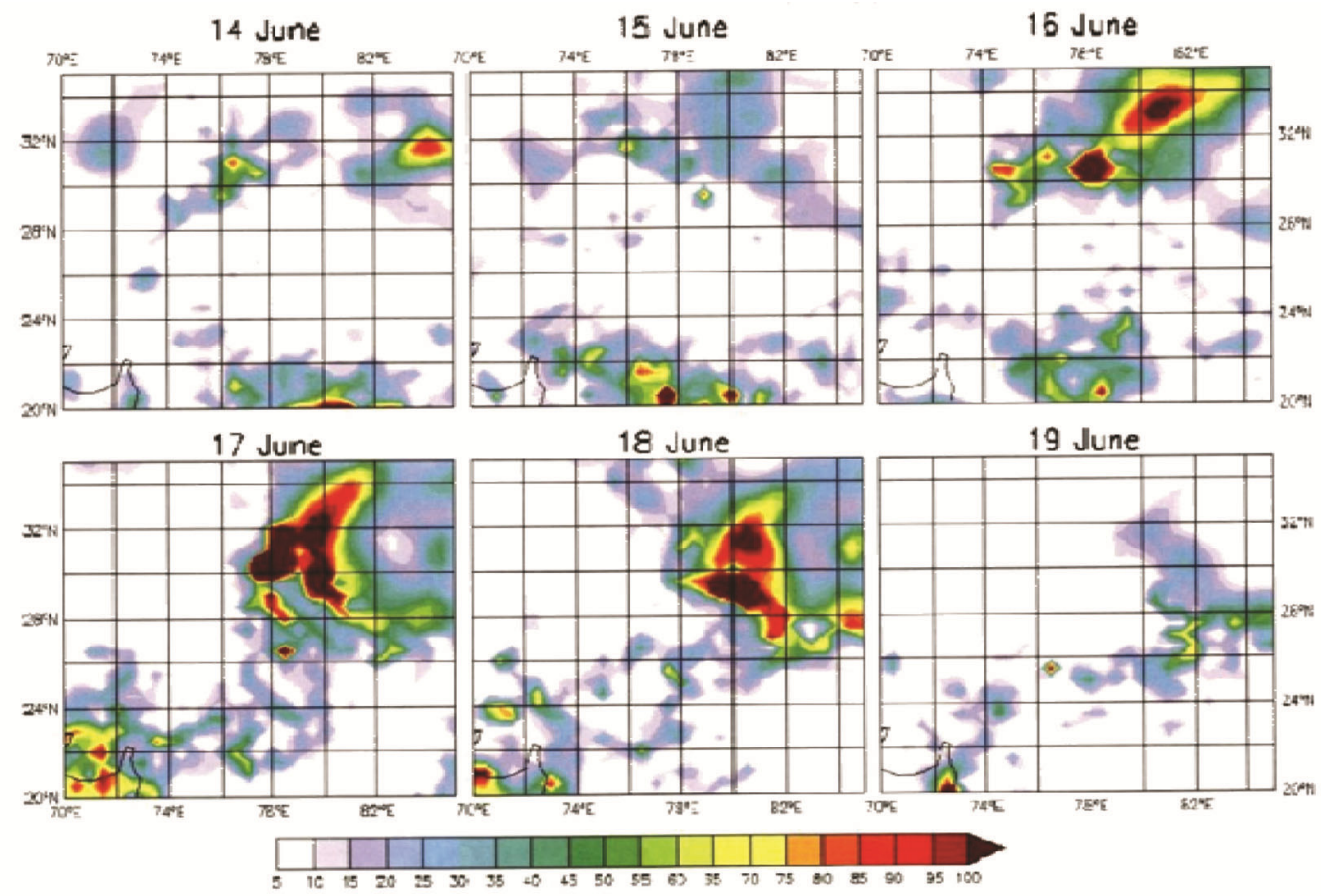

Figure 1. Spatial distribution of rainfall $(\mathrm{mm} / \mathrm{d}$; India Meteorological Department (IMD) and National Centre for Medium Range Weather Forecast (NCMRWF) satellite and rain gauge merged data) at Kedarnath and downstream region showing intense and localized rainfall over the region during the period 14-19 June 2013.

pressure systems and western disturbances (WDs) coincide with ISM to produce heavy rainfall and floods ${ }^{10,11}$. Average frequency of extreme rainfall events has increased and contribution of extreme events to the total monsoon rainfall has also increased over the Indian region during the period 1951-2005 (ref. 12). Further, although the number of depressions and cyclonic storms has declined in recent decades, there is an increase in the intensification of cyclones to severe cyclones over the Indian seas ${ }^{13}$. All these studies suggest that the most likely cause of recent increase in extreme flood events is the higher frequency of extreme rainfall events. Frequency and duration of rainstorms over the monsoon region exhibit increasing trends ${ }^{14}$. During 1951-2015, an increase from 4 to 8 rainstorms per year and from 12 to 27 rainstorm days per season have been observed. They suggest a substantial increase in the risk of large-scale floods during ISM in India.

Higher rainfall variability is related to the occurrence of extreme rainfall events and their intensities. Extreme rainfall over the Western Ghats and central parts of the Indian Peninsula shows significant increasing trend. Stations over the southern Indian Peninsula and the lower Ganga valley exhibit a decreasing trend. Most of the studies on extreme rainfall events over India used data from limited number of stations ${ }^{15,16}$. However, their results are useful for disaster management.

Floods are ranked based on their severity. Some severe floods are catalogued ${ }^{17}$. Flood-producing rainstorms have also been studied from a hydrological point of view. During the period 1880-1990, 97 severe rainstorms leading to floods have been identified ${ }^{18}$. Interestingly, except for a few severe rainstorms, most others have preferred zones of flooding in the northern, central and peninsular India. The worst flood events mostly occur in the IndoGangetic plains ${ }^{9}$. Based on the global active archive of Large Flood Events dataset and flood magnitude indices, 32 extreme floods between 1985 and 2013 have been catalogued. These events with $\sim 100$ years return period, have an average frequency of $\sim 2$ events per year. Monsoon rainfall of Mumbai in July 2000 led to extreme flooding and severe waterlogging. Vulnerability of Hyderabad to August 2000 flood, questioned the planning of urban development ${ }^{19}$.

The heavy rainfall event of 26 July 2005 leading to floods in Mumbai has been studied by several workers ${ }^{20-24}$. Formation of meso-scale convective system over Mumbai, comprising super thunderstorm cells and their interaction with the synoptic-scale low-pressure area from the Bay of Bengal are considered to have led to very high rainfall.

\section{Floods due to interaction of ISM and mid-latitude westerlies}

During ISM, westerly troughs pass across subtropical latitudes and occasionally extend southward up to northern India and Pakistan. Interactions between the westerlies 


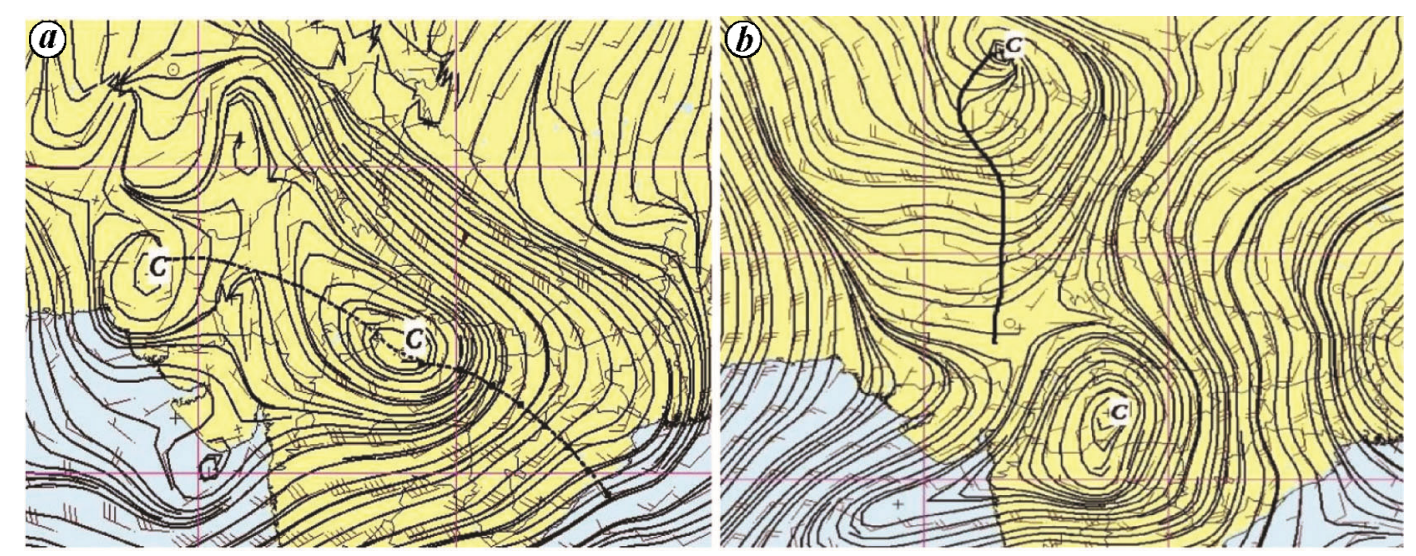

Figure 2. Analysis of (a) $850 \mathrm{hPa}$ and (b) $500 \mathrm{hPa}$ flow on 16 June 2013 (based on IMD GFS-T574 model: the model description and details are not discussed here due to brevity of the paper). It shows low pressure over central India and southern Pakistan at $850 \mathrm{hPa}$. In case of $500 \mathrm{hPa}$, low pressure region over central India and northern Pakistan is seen. It shows low pressure associated with Western Disturbance (WD) at higher level which merged with the low-level low pressure system and intensified the cumulative impact.

and ISM systems have been debated for a long time ${ }^{25}$. The interaction of ISM and WDs embedded in the westerlies leads to hiatus in monsoon advance, and beginning and persistence of the 'break' monsoon during July-August. Occasional presence and interaction of WDs intensify $\mathrm{ISM}^{26,27}$. Interlocking/merging of WDs with the ISM ITCZ invigorates the monsoonal flow. Interaction between these two systems depends upon the status of monsoon activity at the start of the interaction period $^{28}$. If monsoon is in the weakening phase, the approach of a westerly trough would enhance 'break' condition, and if the monsoon is in the intensifying stage, the interaction would result in enhancement of rainfall. The latter happened during 16-17 June 2013 Uttarakhand flood and 4-6 September 2014 Srinagar flood. There were other flood events too when such interactions resulted in severe rainfall over-northwest India and Gujarat regions ${ }^{11,29}$.

\section{June 2013 Uttarakhand flood}

The 16-17 June 2013 Uttarakhand flood caused massive destruction of life and property. Along the Kedarnath valley, heavy rainfall led to flashfloods in the Mandakini and Saraswati rivers. In addition, glacial lake outburst flood (GLOF) from Mahatma Gandhi Sagar due to glacier/ snow melt along with glacial moraines increased surface run-off towards Kedarnath and downstream ${ }^{30}$. Figure 1 depicts intense and localized rainfall in the region during the period 14-19 June 2013. Dynamical interaction between the west-northwest-moving monsoon low pressure system and the eastward-moving mid-latitude $\mathrm{WD} /$ westerly trough, led to heavy to very heavy rainfall ${ }^{10}$ (Figure $2 a$ and $b$ respectively). A WD/upper level westerly trough in the extra tropical latitudes began to penetrate southward over North India from northwest
Pakistan. At the same time a monsoon low, developed over north Bay of Bengal, moved west-northwest across northern India, weakening slowly during its progress. The upper trough remained quasi stationary between 15 and 17 June 2013, while the monsoon low came in phase with it during 16-17 June 2013. A low pressure system associated with low-level easterly on and along the Gangetic plain caused convergence for moisture incursion over the northwestern part of India ${ }^{31}$. During the Uttarakhand flood, merging of WD with monsoon trough led to an occluded discontinuity and provided pulsatory extension of monsoon (PEM) over Uttarakhand Himalaya. This discontinuity formed due to cold gradient of the frontal WD in the upper troposphere (leading section warmer and trailing section colder), and warmer and more humid monsoon flow in the lower troposphere. Thus, highresolution modelling and observational assessments of these interactions provided an understanding of the associated mechanisms relevant to hazard mitigation and decision-making ${ }^{27}$. Such a situation increased potential instability of air mass along the valley recesses, which is capped by an inversion located above the ridgeline. In addition, strengthening of the northwesterly flow above the ridges supported the lifting of the potentially unstable air over the protruding ridge at the foothills of the Himalaya and triggered shallow convection, which on passing through adjacent folds initiated deep convection. This mechanism provided the initial convective trigger for convective storms to originate within the deep valley and ridges.

\section{September 2014 Srinagar flood}

A continuous spell of very heavy rainfall for five days in the first week of September 2014 caused disastrous floods in many parts of the northwestern state of Jammu 
Table 1. All-time record of $24 \mathrm{~h}$ rainfall (mm) over Jammu \& Kashmir (J\&K), India

\begin{tabular}{|c|c|c|c|c|c|}
\hline \multirow[b]{2}{*}{ Station } & \multicolumn{3}{|c|}{ Previous record } & \multicolumn{2}{|c|}{2014} \\
\hline & Period & $24 \mathrm{~h}(\mathrm{~mm})$ & Date & $24 \mathrm{~h}(\mathrm{~mm})$ & Date \\
\hline Anantnag & 1901-1982 & 149.4 & 01.09 .1928 & 180 & 04.09 .2014 \\
\hline Kukernagh & 1979-2011 & 135.8 & 25.02 .1987 & 149.5 & 05.09 .2014 \\
\hline Qazi gund & $1962-2013$ & 160.9 & 09.09 .1966 & 206 & 06.09 .2014 \\
\hline Banihal & $1962-2013$ & 205.6 & 28.08 .1997 & 188.8 & 05.09 .2014 \\
\hline Batote & 1979-2011 & 255.4 & 23.08 .1996 & 208 & 05.09 .2014 \\
\hline Katra & 1980-2011 & 292.4 & 25.09 .1988 & 279.2 & 04.09 .2014 \\
\hline
\end{tabular}

Table 2. All-time record of $48 \mathrm{~h}$ cumulative rainfall $(\mathrm{mm})$ in $\mathrm{J} \& \mathrm{~K}$

\begin{tabular}{|c|c|c|c|c|c|}
\hline \multirow[b]{2}{*}{ Station } & \multicolumn{3}{|c|}{ Previous record } & \multicolumn{2}{|c|}{2014} \\
\hline & Period & $48 \mathrm{~h}(\mathrm{~mm})$ & Date & $48 \mathrm{~h}(\mathrm{~mm})$ & Date \\
\hline Anantnag & 1901-1982 & 186.7 & 13.01 .1903 & 238.4 & 03.09 .2014 \\
\hline Kukernagh & 1979-2011 & 176.1 & 27.08 .1997 & 268.9 & 04.09 .2014 \\
\hline Qazi gund & $1962-2013$ & 282.3 & 27.08 .1997 & 362.7 & 05.09 .2014 \\
\hline Banihal & $1962-2013$ & 310.4 & 18.02 .2003 & 300.3 & 04.09 .2014 \\
\hline Batote & 1979-2011 & 363.6 & 23.08 .1996 & 331 & 05.09 .2014 \\
\hline Katra & 1980-2011 & 418.4 & 22.08 .1996 & 488.6 & 04.09 .2014 \\
\hline
\end{tabular}

Table 3. All-time record of $72 \mathrm{~h}$ cumulative rainfall $(\mathrm{mm})$ in $\mathrm{J} \& \mathrm{~K}$

\begin{tabular}{lllllll}
\hline & \multicolumn{3}{c}{ Previous record } & & \multicolumn{2}{c}{2014} \\
\cline { 2 - 3 } \cline { 6 - 6 } Station & Period & $72 \mathrm{~h}(\mathrm{~mm})$ & Date & & $72 \mathrm{~h} \mathrm{(mm)}$ & Date \\
\hline Anantnag & $1901-1982$ & 210.8 & 16.09 .1950 & & 244.8 & 02.09 .2014 \\
Kukernagh & $1979-2011$ & 194.5 & 26.07 .1995 & & 357.5 & 04.09 .2014 \\
Qazi gund & $1962-2013$ & 300.7 & 17.02 .2003 & & 519.4 & 04.09 .2014 \\
Banihal & $1962-2013$ & 392.5 & 17.02 .2003 & & 389.3 & 03.09 .2014 \\
Batote & $1979-2011$ & 434 & 22.08 .1996 & & 433 & 04.09 .2014 \\
Katra & $1980-2011$ & 544.2 & 22.08 .1996 & & 698.6 & 04.09 .2014 \\
\hline
\end{tabular}

and Kashmir (J\&K). The region is prone to deep convection during monsoon ${ }^{32,33}$. Floods occurred in $\mathrm{J} \& \mathrm{~K}$ and neighbouring states due to the recurving of depressions over Rajasthan towards north or northeast ${ }^{34}$. Deep penetration of moisture occurred due to the presence of lows in the lower troposphere associated with trough in the upper level westerlies with an embedded jet stream $^{35}$. Continuous heavy rainfall is caused due to interaction between the westward-moving monsoon low and eastward-moving deep trough in the mid-latitude westerlies ${ }^{36}$. Historical rainfall data of the state show that the event was unprecedented and can fall in the 'never before' category. Tables 1-3 present accumulated rainfall data over J\&K at 24,48 and $72 \mathrm{~h}$ respectively, for some IMD stations. The 24, 48 and $72 \mathrm{~h}$ rainfall at Anantnag, Kukernag and Quazigand surpassed the previous records, while the 48 and $72 \mathrm{~h}$ rainfall exceeded at Katra.

\section{July 2017 Gujarat flood}

Rajasthan and Gujarat are two states of India with annual rainfall of 48 and $70 \mathrm{~cm}$ respectively. Though major parts of these states are in the arid region, occasionally they experience intense rainfall activity of more than $200 \mathrm{~mm} /$ day. The major synoptic systems responsible for such heavy rainfall are lows/depressions moving from the Bay of Bengal, cyclonic storms from the Arabian Sea and mid-tropospheric cyclones forming over Gujarat coast. Torrential rainfall caused the Gujarat and Rajasthan floods during 23-25 July 2017. On 24 and 25 July 2017, heavy rainfall $(>25 \mathrm{~cm} /$ day) was recorded at a number of stations (Table 4). A number of stations recorded rainfall nearly equal to or more than that of a whole season. The station at Mount $\mathrm{Abu}$ recorded around $1500 \mathrm{~mm}$ of rainfall in $48 \mathrm{~h}$ on 23 and 24 July 2017. Several stations in Banaskantha recorded $600-800 \mathrm{~mm}$ of rainfall in $48 \mathrm{~h}$ on the same days (Figure $3 a$ and $b$ ). The anomalous heavy rainfall was due to two low pressure systems, simultaneously present over south Rajasthan and neighbouring regions with associated upper air cyclonic circulation extending up to $7.6 \mathrm{~km}$ amsl and another over Gangetic West Bengal and adjoining Jharkhand extending up to $9.5 \mathrm{~km}$ amsl (Figure 4). Intense rainfall over southeast Rajasthan and adjoining north Gujarat occurred due 
Table 4. Extremely heavy rainfall recorded at some of the stations in Rajasthan and Gujarat on 24 and 25 July 2017

\begin{tabular}{lllcr}
\hline State & District & Station & $\begin{array}{c}\text { 24 h Cumulative rainfall } \\
\text { recorded on 24 July (mm) }\end{array}$ & $\begin{array}{r}\text { 24 h cumulative rainfall } \\
\text { recorded on 25 July (mm) }\end{array}$ \\
\hline Rajasthan & Jalor & Raniwada & 388 & 170 \\
& & Bhinmal & 257 & 81 \\
& Pali & Jawai Dam & 230 & 29 \\
& Sirohi & Mount Abu & 773 & 733 \\
& & Reodar & 403 & 451 \\
& & Sirohi & 380 & 300 \\
Gujarat & Abu Road & 266 & 272 \\
& Banaskantha & Dantiwada & 342 & 463 \\
& & Amirgadh & 246 & 337 \\
& & Deesa & 248 & 269 \\
& & Dhanera & 231 & 275 \\
& & Palanpur & 255 & 380 \\
\hline
\end{tabular}
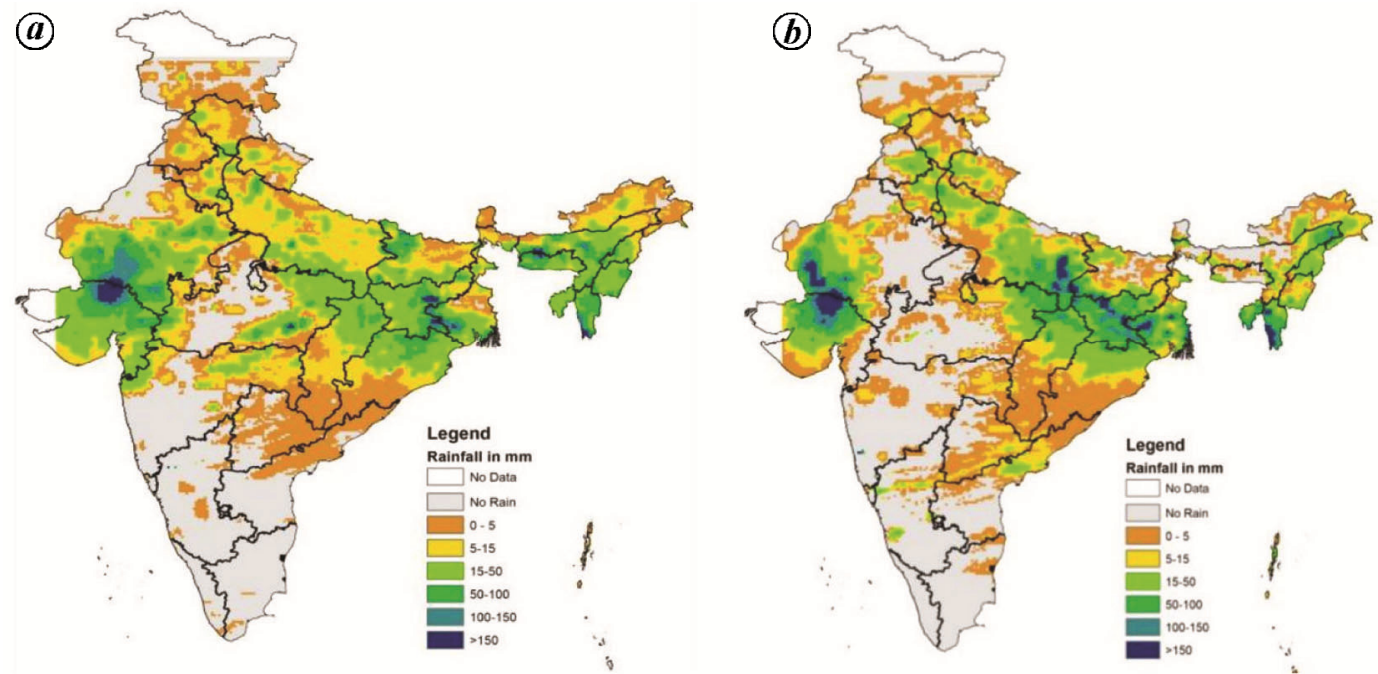

Figure 3. NOAA CPC rainfall map on (a) 23 July 2017 and (b) 24 July 2017.

to interaction with the westerly trough extending at $500 \mathrm{hPa}$ along $72^{\circ} \mathrm{E}$ long. and $32^{\circ} \mathrm{N}$ lat. due to a WD passing over $\mathrm{J} \& \mathrm{~K}$ and neighbouring region between 3.1 and $5.8 \mathrm{~km}$ amsl (Figure 5). An east-west trough extended from north Gujarat to Gangetic West Bengal at $500 \mathrm{hPa}$ level. The air masses ordinarily present over Rajasthan and Gujarat during ISM are moist due to southwesterly to westerly moist air from the Arabian Sea up to about $1.0 \mathrm{~km}$ amsl as a result of cross equatorial flow. The warm and dry air from the west gives rise to stable condition or an inversion ${ }^{37}$. These stable conditions prevent formation of clouds and rainfall over this area. The monsoon disturbances which moved from the Bay of Bengal across central India, along the monsoon trough or the low pressure area that developed in situ over this region were able to replace the dry continental air at higher levels with moist air mass, causing heavy rainfall due to convergence of different air currents ${ }^{38}$. Rainfall in northwest India, including Rajasthan and Gujarat is not only influenced by tropical systems approaching from the east, but also by trailing edge of the westerly trough in the mid and upper troposphere. Both the systems interacted and caused torrential rainfall by sucking up moisture from the Arabian Sea branch of the monsoon ${ }^{25}$. Significant increasing trends in the frequency of heavy and very heavy rainfall events over Gujarat are reported. Rainfall extremes have increased in the past decade over south Gujarat and Saurashtra region ${ }^{39}$. Frequency of heavy rainfall ( $>65 \mathrm{~mm} /$ day) has increased significantly in all districts of Gujarat ${ }^{40}$.

\section{Floods in association with northeast monsoon}

While ISM is responsible for a major portion of the annual rainfall over India, rainfall received during the northeast monsoon (NEM) is important over the 


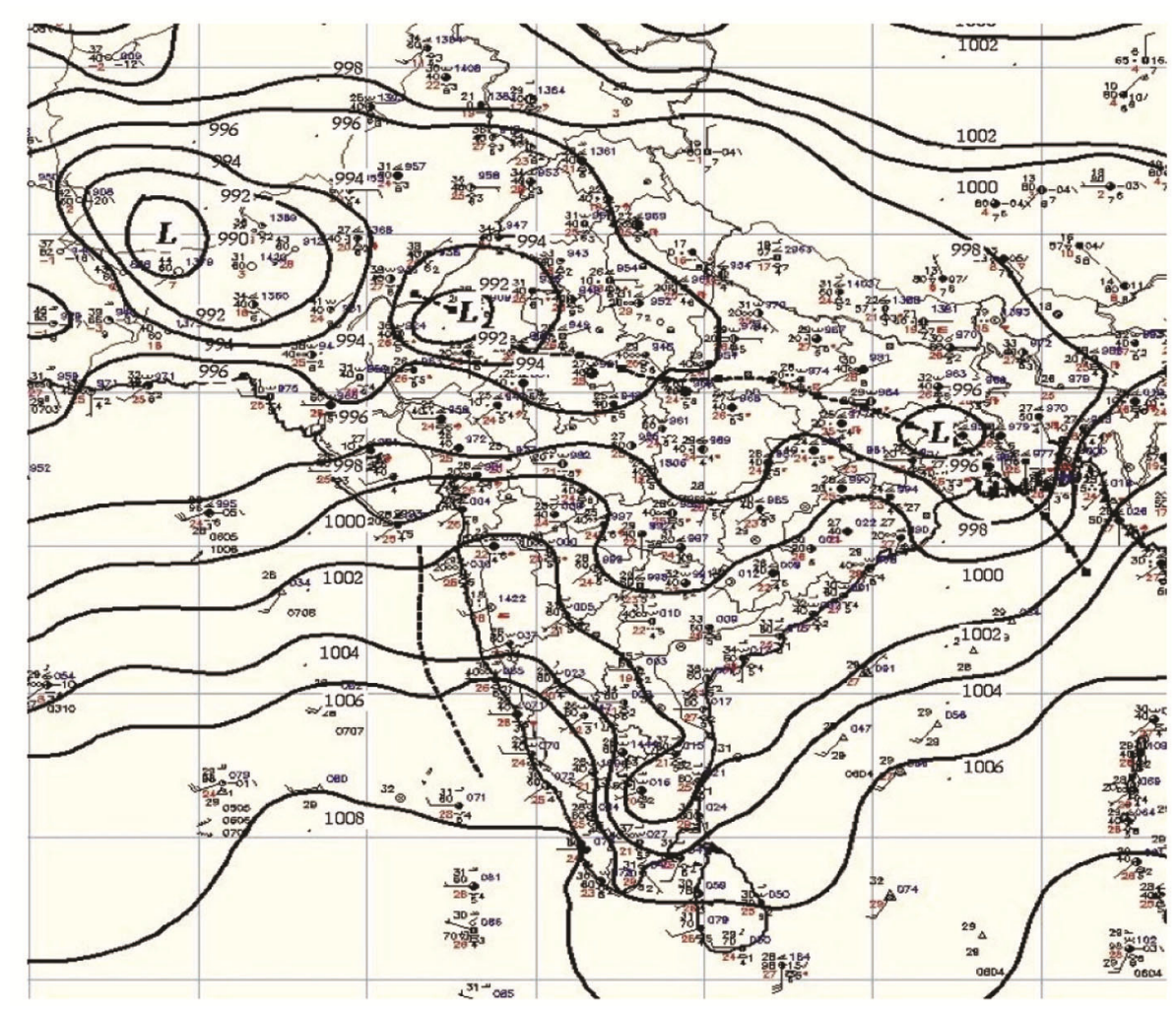

Figure 4. Mean sea level isobaric chart (hPa) of 0300 UTC on 23 July 2017.

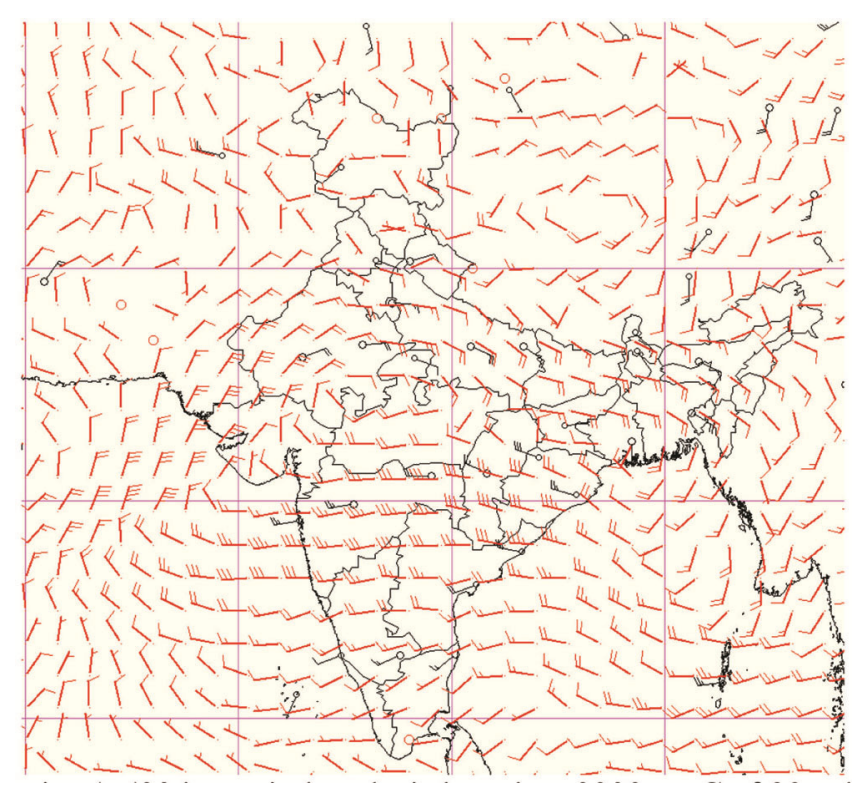

Figure 5. $500 \mathrm{hPa}$ wind analysis of $0000 \mathrm{UTC}$ on 23 July 2017 based on IMD GFS-T574 model.

southeastern coast. During withdrawal phase of ISM, lower-level winds over South Asia reverse their direction from southwest to northeast. This change is associated with southward movement of the continental tropical convergence zone (CTCZ) and the subtropical anticyc- lone ${ }^{41}$. NEM rainfall over southern peninsula is generally attributed to westward-propagating tropical waves near $10^{\circ} \mathrm{N}$ lat. over the Bay of Bengal ${ }^{42,43}$. The trade wind easterlies, and the waves embedded within them, trade wind surges and associated mass convergence also convey moisture, near the $10^{\circ} \mathrm{N}$ zone. The possible role of a large-amplitude extended westerly trough is in trapping and transporting moisture from the ITCZ region of the southern hemisphere to the southeast coast of India ${ }^{44}$. During this period, wind flow over Tamil Nadu and parts of the southern peninsula is generally from the northeast and as the winds veer with height, the flow becomes easterly and southeasterly. In the upper troposphere, the flow becomes southerly to southwesterly, anticyclonic over the Bay of Bengal. The monsoon easterly jet disappears and the weak southerly/easterly prevails between September and November at $150-100 \mathrm{hPa}$. Heavy to very heavy rainfall occurs over Tamil Nadu and coastal Andhra Pradesh during this period, in association with the passage of cyclonic storms and depressions across the area. This contributes to $11 \%$ of the annual rainfall received over India. Coastal Tamil Nadu receives $60 \%$ of its annual rainfall during this period. As far as the NEM is concerned, not much data is available at intra-seasonal scale. Seasonal rainfall of two years (2005 and 2010) was significantly above normal (63\% and 55\% respectively). The increasing trend in NEM rainfall in recent years could be related to the increasing trend in the positive 


\section{REVIEW ARTICLES}

phase of the Indian Ocean dipole mode ${ }^{45}$, which is not discussed here.

\section{December 2015 Chennai flood}

In 2010, NEM rainfall over the southern Indian peninsula was significantly above normal $(155 \%$ of the long-term average), which is the second highest since 1901, next only to 2005. During the 2010 season, five low pressure systems (two severe cyclonic storms, two depressions and one low pressure area) formed over the northern Indian Ocean, which led to heavy rainfall. Tamil Nadu and Puducherry experienced unprecedented rainfall during November and early December 2015, leading to devastating floods. The megacity of Chennai was worst affected during end November and early December (Figure 6). In 2015 , onset of NEM took place on 28 October as against the normal date of 20 October. Subsequently, during November, the following three synoptic-scale weather systems occurred:

- Deep depression over the Bay of Bengal (8-10 November 2015).

- Well-marked low pressure area over southwest Bay of Bengal (12-18 November 2015)

- Low (28 November-4 December 2015).

The total rainfall recorded in Chennai district during 1 November to 5 December 2015 was $1416.8 \mathrm{~mm}$ as against the normal of $408.4 \mathrm{~mm}$. An anomalous midtropospheric high to the west of the Indian region can induce anomalous northerly to the north that does not allow propagating systems to move further north and west. It resulted in dry conditions in the northwest Indian region and wet conditions in the southeast Indian peninsula, i.e. an anomalous high over the Middle East in November resulted in increased rainfall over south India. Sea surface temperature (SST) in the northern and western Bay of Bengal has hardly increased over the past 35 years, in contrast to most of the rest of the world. No effect of global warming in the occurrence of extreme one-day rainfall, that caused widespread flooding in Chennai in December 2015, can be comprehended as yet.

Continuous formation of deep convective clouds and their movement from the Bay of Bengal to Chennai city during all three events and particularly on 1 December 2015 led to torrential rainfall ${ }^{46}$. More than 100 pixels reported $>100 \mathrm{~mm}$ of rainfall during that hour (Figure 7). All these pixels were located in the form of a squall line (approximately 20-30 km north-south, across Adyar river along $80^{\circ} \mathrm{E}$ long.) in the northeast direction of Chennai International Airport (Figure 8). The Doppler Weather Radar (DWR) imagery showed reflectivity and surface rainfall intensity (Figure 9). The unprecedented rainfall in the three episodes resulted due to frequent wind surges (carrying wind of $13-14 \mathrm{~m} / \mathrm{s}$ that moved from east to west along with the easterly wave) (Figure 10). Table 5 shows extreme heavy rainfall recorded on 2 December 2015 over the districts of Chennai, Tiruvallur and Kancheepuram.

\section{Geomorphological aspects associated with the flood events}

\section{June 2013 Uttarakhand flood}

The extreme convergence of two cloud patterns resulted in flash flood in glacial-fed streams in the upper reaches in Ganga river (Figure 1) ${ }^{11}$. The GLOF along Kedarnath valley is one of the better documented examples from the Himalayan region ${ }^{30}$. The high gradient $(>100 \mathrm{~m} / \mathrm{km})$ tributary streams, connecting glacial outwash to the trunk channels with lower gradient $(<50 \mathrm{~m} / \mathrm{km})$ like the Alaknanda river, experienced massive sediment mobilization from oversaturated glacial debris source and bedrock erosion along the gorges. The loss of stream gradient along the trunk channel reduced the carrying capacity of the run-off, causing growth of large debris fan that temporarily blocked the trunk channel and produced high flood

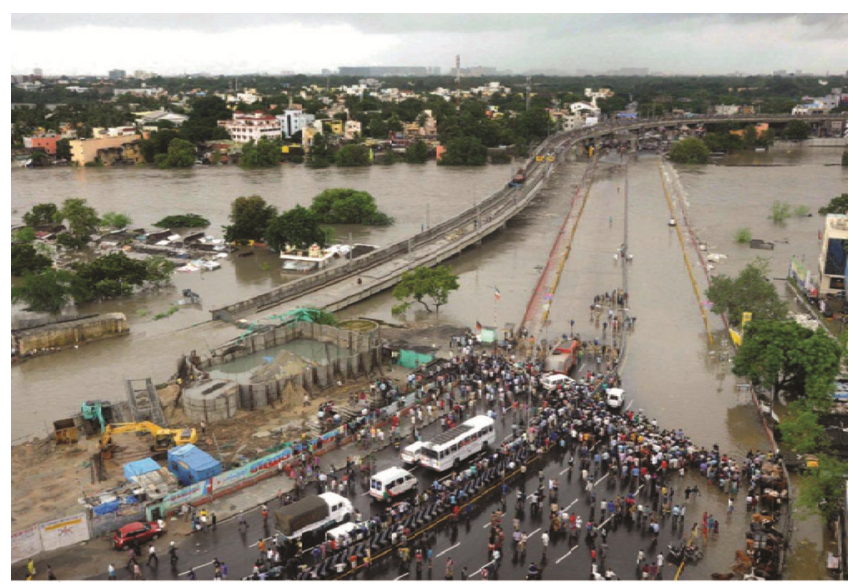

Figure 6. Flooding in Chennai on 2 December 2015.

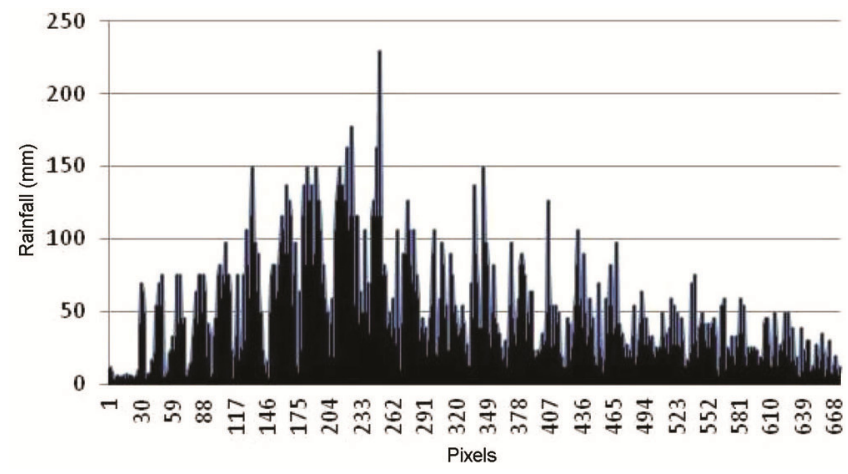

Figure 7. Spatial variation of rainfall intensity over Chennai district between 0000 and 2300 UTC on 1 December 2015 based on Doppler weather radar. 
levels inundating and eroding lower banks, also choking the small captive reservoir of hydroelectric project ${ }^{47}$. Similar hazardous ephemeral landform growth was observed during the 1978 Dabrani flash floods along the Bhagirathi river.

At a lower topographic level, $<1500$ above mean sea level, the trunk streams flow on wider confined valley floors as braided rivers with lenticular mid-channel bars, cut-off banks and point bars with gentle gradient $(\sim 10 \mathrm{~m} / \mathrm{km})$ in the Himalayan terrain (Figure $11 a$ ). These rivers with gravel bed pass through multiple levels of strath and fill terraces along the Bhagirathi, Mandakini and Alaknanda rivers, cause widespread toe erosion and slope failure by channel migration, extensively damaging habitats, roads and other infrastructure facilities (Figure $11 \mathrm{~b}$ ). However, the larger Alaknanda and Bhagirathi, flowing as braided rivers, with occasional anastomosing channels over 2 $3 \mathrm{~km}$ wide flood plains in certain stretches (Figure 11a) experienced extensive cut-off bank erosion, river avulsion (Figure $11 \mathrm{c}$ ) and overbank flooding with deposition of large bed-load sediments (Figure $11 \mathrm{~b}$ ). The trees in the flood plain and lower terraces were also uprooted. The excavation dump of the hydro-electric project (Figure 11 a) upstream of Srinagar (Garhwal) township also contributed to the bed load of the Alaknanda river choking

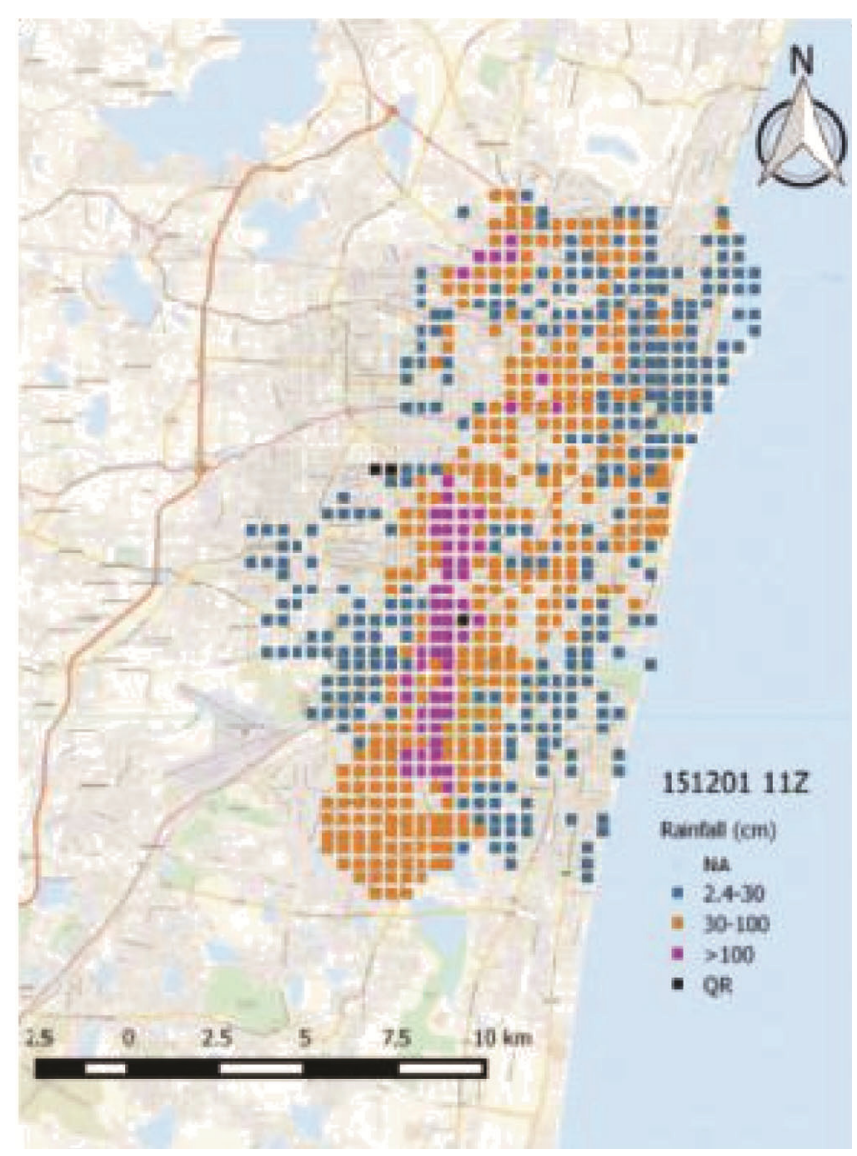

Figure 8. Radar coverage over Chennai district between 1000 and 1100 UTC on 1 December 2015. the settlements on the lower terraces of Srinagar township (Figure $11 b$ ). The June 2013 flood level in Srinagar township surpassed that of the 1970 Alaknanda flood, which was caused by Gohna Tal landslide lake outburst flood (LLOF) ${ }^{48}$ that was triggered by higher cumulative rainfall-driven run-off from the Alaknanda, Mandakini and Pindar rivers. These observations indicate that when an episode of incessant rainfall over a larger catchment area once exceeds the run-off, it will cause devastating floods on regional scale thereby affecting lower terraces of rivers in the hilly terrain in comparison to the LLOF, e.g. 1970 Alaknanda LLOF. Despite the 1970 experience, lower terraces in the floodway were occupied by habitation, which led to sufferings due to flood inundation during the June 2013 event.

The region affected by the June 2013 flood disaster witnessed surge in infrastructural growth ${ }^{47}$, having varied effect on the ensuing disaster. The large infrastructural projects like Tehri reservoir on Bhagirathi river acted as a local sink for the June 2013 flood and associated bed load, including massive pile of uprooted trees. The Tehri reservoir prevented flood run-off into the Ganga river, thereby reducing flood intensity and disaster in the Ganga plains. However, the Hathinikund Barrage located at the mountain exit of the Yamuna river released $>1.1$ million cusecs flood run-off to the natural flood plain/floodway of the river between 16 and 19 June 2013 (press bulletin of the Irrigation and Flood Control Department of Haryana). This caused massive flooding in the Yamuna plains, with flood level touching the historic high of 1978 in Delhi. The reclamation/encroachments of lower terraces, flood plains and floodways for short-term economic benefits ignoring the inherent hazard potential has adversely affected the region during the June 2013 disaster (Figure $11 d$ ), and may happen again in future.

\section{September 2014 Srinagar flood}

The bowl-shaped Kashmir valley is drained by the Jhelum river and its tributaries. The rivers pass through several wetlands and lakes along the valley axis before exiting through a narrow gorge near Baramulla (Figure $12 a$ ). The narrow exit point with a small cross-sectional area of the Jhelum river and the gentle topography with $<4 \mathrm{~m}$ of relative relief (Figure $12 a$ ) cause extensive development of very large shallow wetlands upstream of Baramulla, with perennial stagnant water. These wetlands act as a local base level for the tributary streams in the region. The basin floor, including the natural levee along the meandering river banks (Figure 12b) has been occupied for a millennium and has experienced recurrent floods of different scales. Historical flood and earthquake records of the region show that large earthquakes occurred in $\mathrm{AD} 825$ and 1885-1886, and blocked the exit mouth of Jhelum river causing extensive flooding in the 


\section{REVIEW ARTICLES}

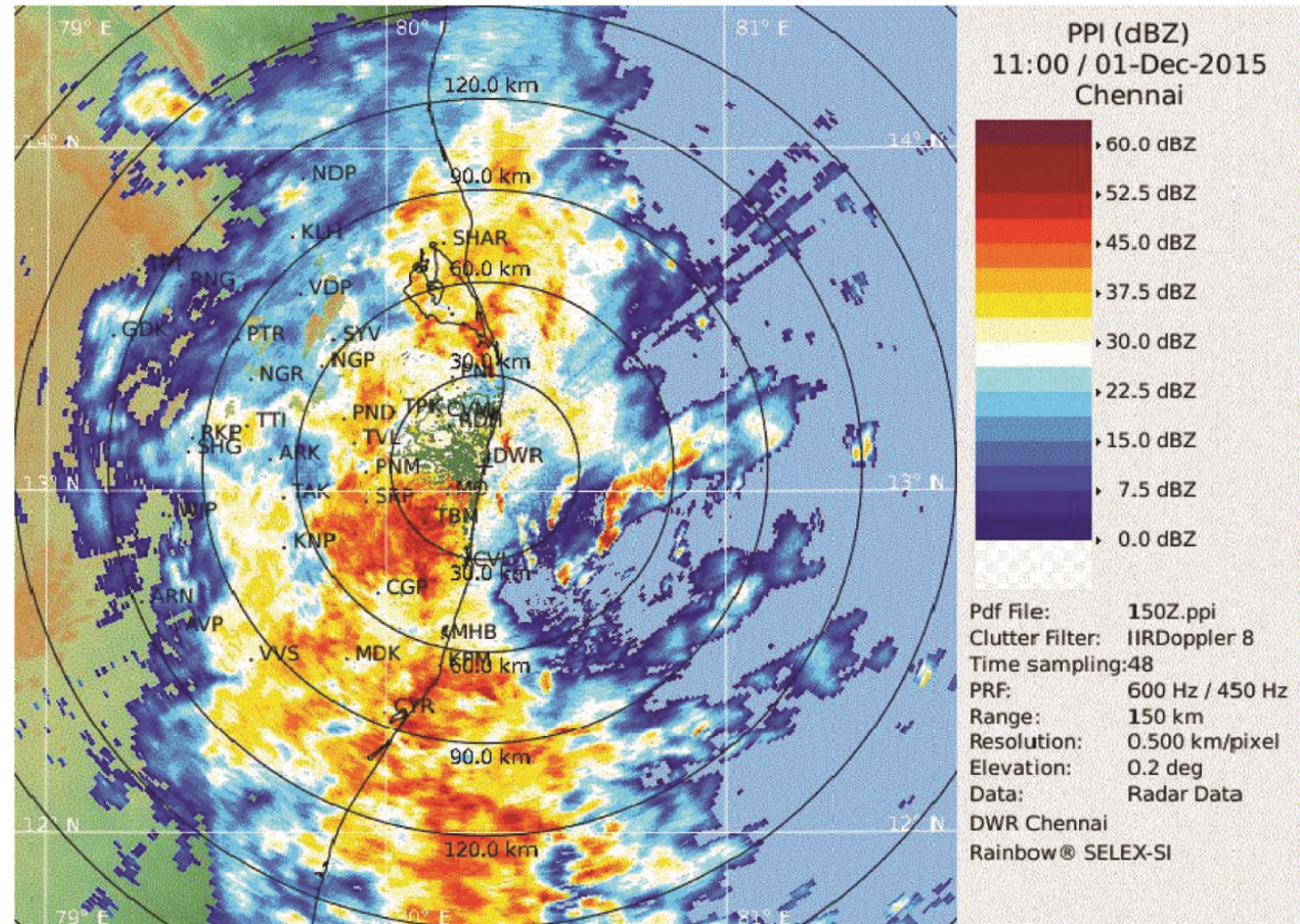

Figure 9. Reflectivity (dBZ) for Chennai district during the cloud burst hour (1100 UTC on 1 December 2015).

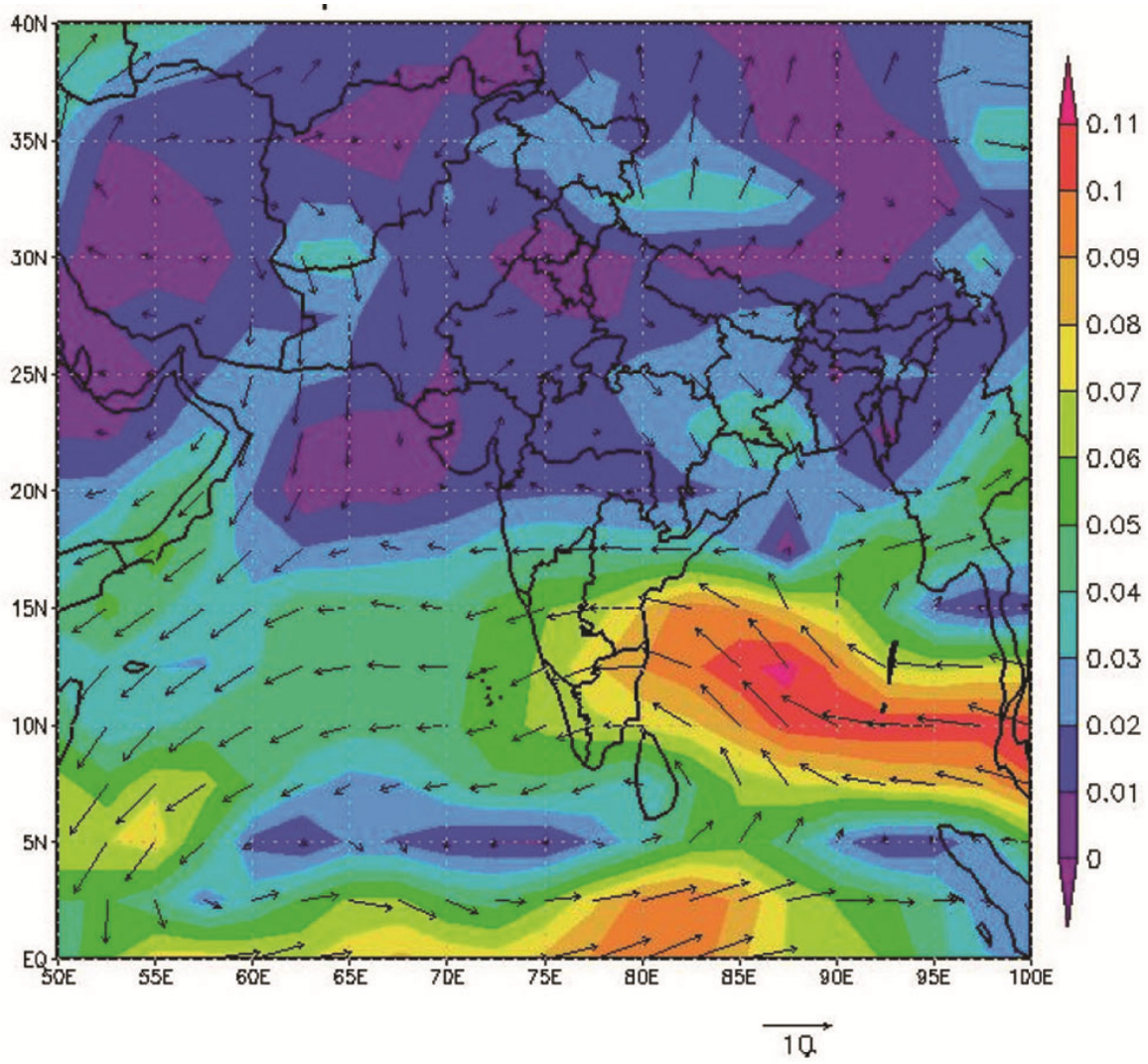

Figure 10. Wind Surge and moisture flux $\left(\mathrm{kg}^{*} \mathrm{~m}^{-1} \mathrm{~s}^{-1}\right)$ at $850 \mathrm{hPa}$ of $0000 \mathrm{UTC}$ on 1 December 2015. 
REVIEW ARTICLES

Table 5. Twenty-four hours cumulative rainfall recorded in Chennai, Tiruvallur and Kancheepuram districts at $0830 \mathrm{~h}$ on 2 December 2015

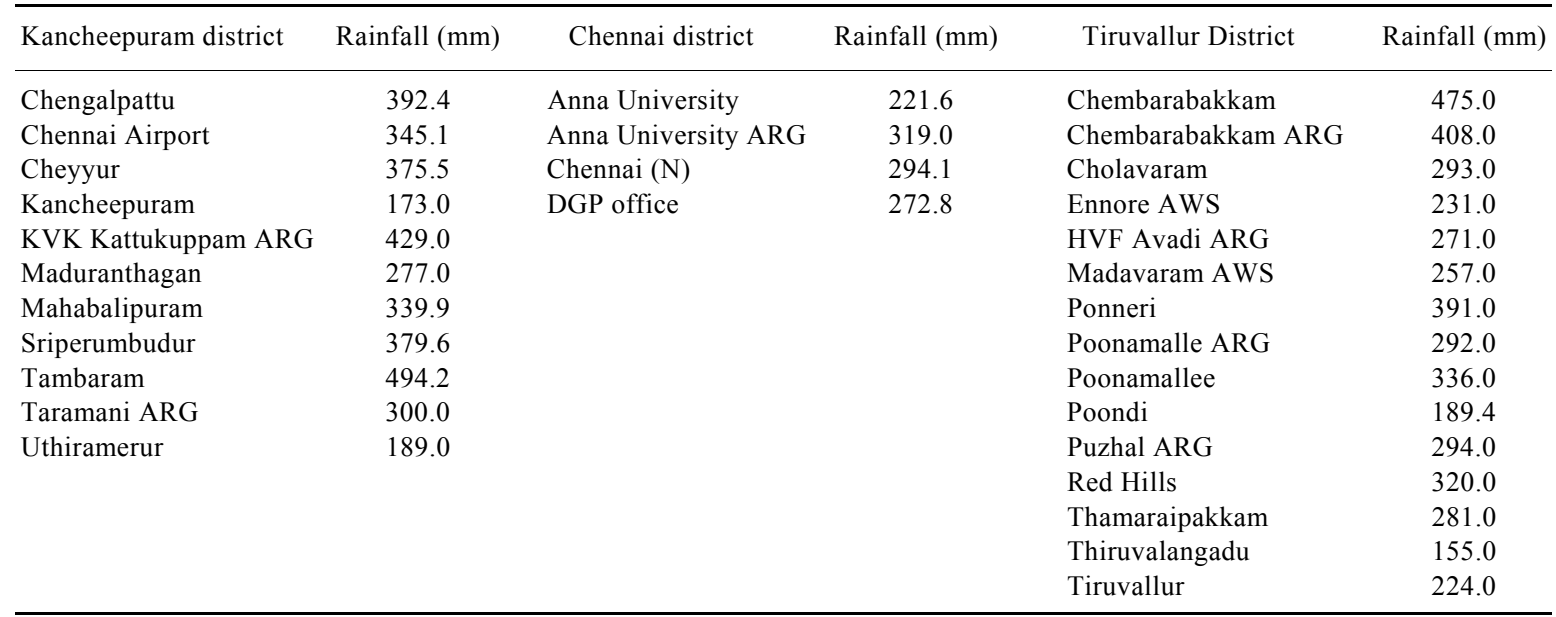

ARG, Automatic rain gauge; KVK, Krishi Vigyan Kendra; HVF, Heavy Vehicle Factory; AWS, Automatic Weather Station.
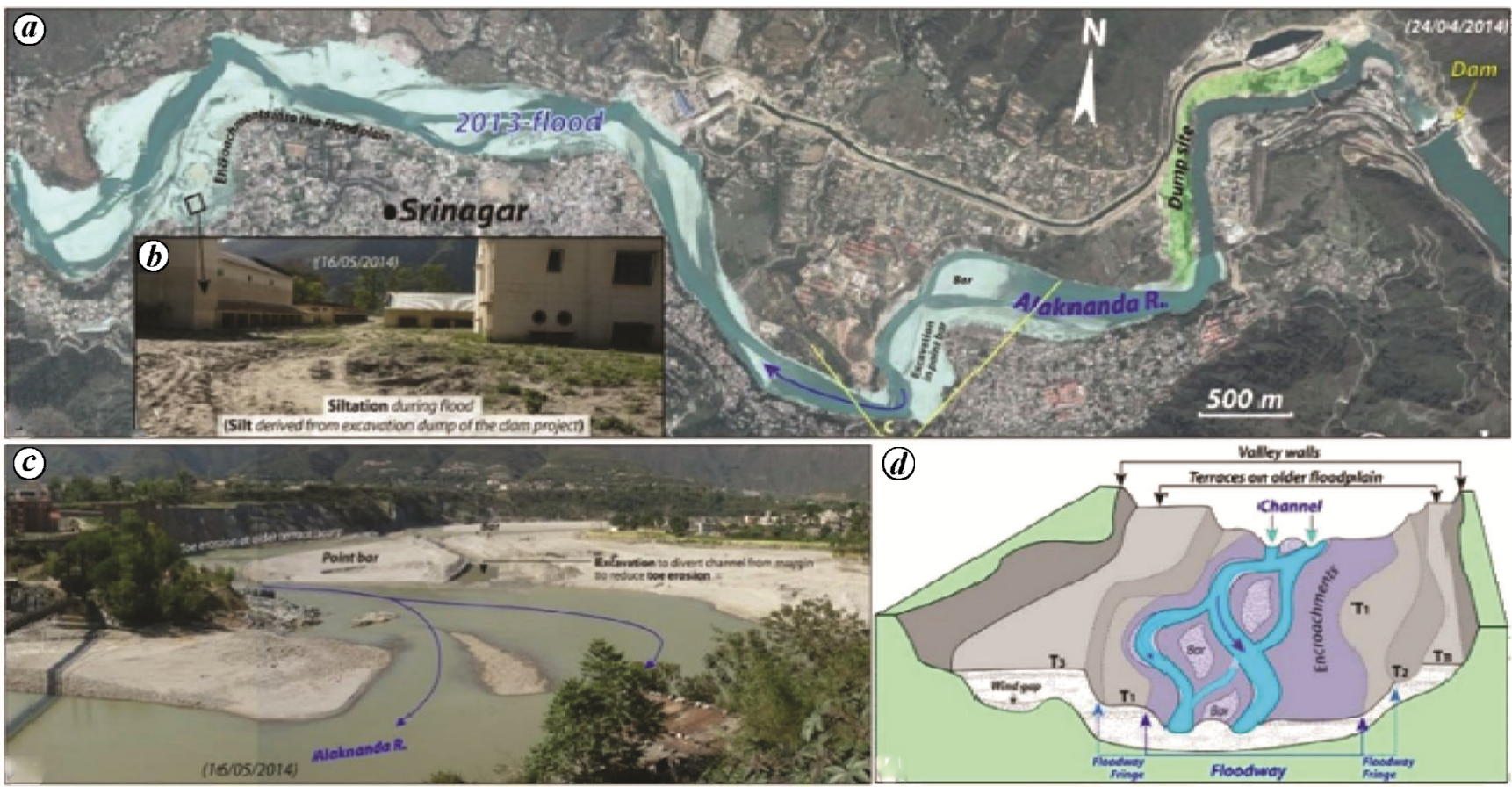

Figure 11. a , Google image of Srinagar (Garhwal) Uttarkhand, overlaid with the submerged lower terrace along the Alaknanda river during the June 2013 flooding. $\boldsymbol{b}$, Industrial Training Institute and other Government buildings choked by silt up to more than 6 feet. $\boldsymbol{c}$, Toe erosion of cut-off bank and flooding of point bar with manually made canal akin to the avulsion channel as immediate flood control measure. $\boldsymbol{d}$, Schematic diagram showing flooding of lower terrace encroachments in such confined meander channel during flooding.

Kashmir Basin, akin to the formation of landslide lakes ${ }^{49,50}$. As a flood protection mechanism, a flood canal was built in 1904 to bypass Srinagar town from flood run-off. The floods of 1928 and 1959 are other notable events in the Kashmir valley.

During the first and second week of September 2014, Kashmir valley experienced incessant rainfall during retreating monsoon over a large catchment area, which produced massive run-off resulting in the biggest flood in the past 100 years $^{51}$ (http://bhuvan-noeda.nrsc.gov.in/ disaster/disaster/disaster.php). The surface run-off exceeded the carrying capacity of the constricted Jhelum river course and the flood canal, which resulted in lateral spill over the banks and inundated the flood plain with a few metres of water column (Figure $12 b$ and $c$ ). The comparative study of satellite imagery (Figure $12 b$ ) suggests that the region has witnessed rapid urbanization during past couple of decades causing haphazard encroachment of the river banks ${ }^{51}$, including the flood canal and at places creating during excavation/altering the 


\section{REVIEW ARTICLES}
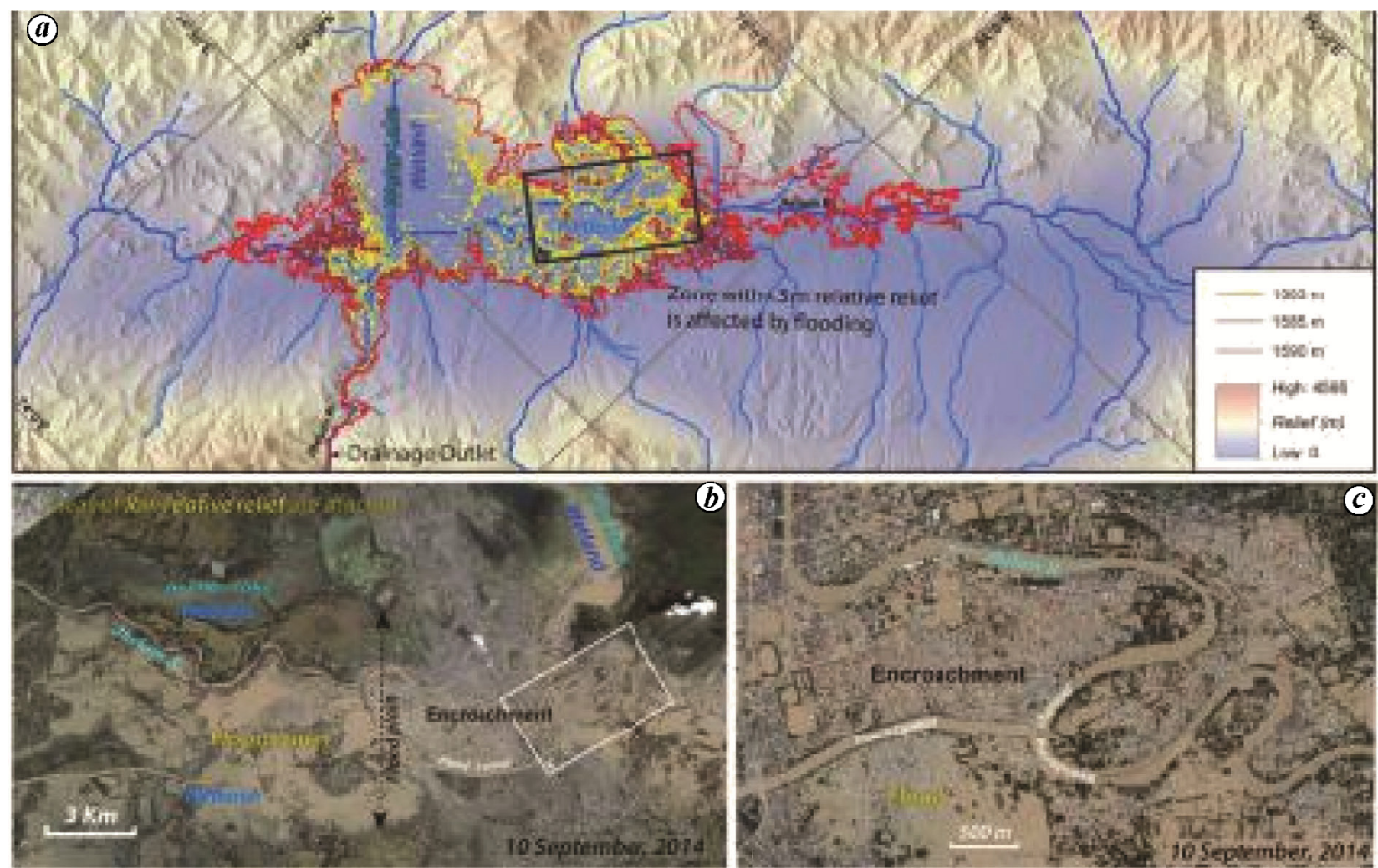

Figure 12. $\boldsymbol{a}$, Relief map of Kashmir valley overlaid with the contours of 1583, 1585 and $1590 \mathrm{~m}$ amsl, which depicts bulk of the valley axis inundated during flooding with $\sim 3 \mathrm{~m}$ relief from the base level of $\sim 1583 \mathrm{~m}$. $\boldsymbol{b}$, Google image of Kashmir flood on 10 September 2014 , showing inundation of low-lying areas within $1585 \mathrm{~m}$ contour; the region is undergoing rapid infrastructural growth encroaching the floodplain. $c$, The meandering Jhelum clearly depicting a mature stage of the river, which is encroached by residential growth, including the flood canal.

natural slopes ${ }^{52,53}$. Flood water remained stagnated in local depressions even after water level in the Jhelum receded due to clogging of natural drainage network. The studies prior to the flood event suggest the danger of rapid urbanization, deforestation and unrestrained land-use changes, including encroachment in the wetlands like littorals of Dal, Anchar, Hokrasar and Narkara, causing a substantial reduction in their size ${ }^{53}$. During the last three decades (1972-2004), the built-up area within Srinagar city limits has grown by about $29.20 \%$ (from $18.10 \mathrm{sq} . \mathrm{km}$ to $84.50 \mathrm{sq} . \mathrm{km})$, which is nearly three times the rate of population growth ${ }^{51,52}$, and observations clearly point towards encroachment of natural flood ways. These studies clearly warned that the depletion and degradation of wetlands due to excessive siltation, rapid urbanization and encroachments has an adverse impact on their efficacy to retain flood waters, including flashflood waters during peak discharge, and need urgent restoration $^{54,55}$. Their assertions proved accurate during the September 2014 flood event. It requires serious thinking, including declogging of the floodways assisted by integrated analysis of the drainage morphometry, dynamic changes in land use/cover that affect changing hydrological behaviour of the basin for sustainable watershed runoff and wetland management activities.

\section{December 2015 Chennai flood}

The occurrence of flood during November-December 2015 and several recent major floods, viz. 1976, 1985, 1996, 1998, 2005, affected coastal districts of Tamil Nadu, including Chennai and adjoining regions causing enormous loss of life, habitat, infrastructure and economy (http://bhuvan-noeda.nrsc.gov.in/disaster/disaster/disaster. php). To understand the flood in Chennai, we analysed the geomorphic set-up and encroachment around the region. Chennai has a gentle sloping substrate with $0-11 \mathrm{~m}$ elevation and average elevation $\sim 6 \mathrm{~m}$ amsl (Figure 13). The pediment and buried pediment substrate of Chennai region is primarily constituted of Archaean crystallines, Gondwana and Tertiary sediments which are covered by alluvium, sand dunes, beach ridges, freshwater marshlands, estuaries and backwaters. The region is drained by Kosasthalaiyar, Cooum and Adyar rivers. Pallikaranai freshwater marshland and the brackish water Buckingham Canal (Figure 13) with many lakes, have profound control on the surface hydrology and run-off of the region.

During the 2015 flood, the low-lying regions between Adyar and Cooum rivers were the most affected (http://bhuvan-noeda.nrsc.gov.in/disaster/disaster/disaster. php). The Adyar river received additional release of 


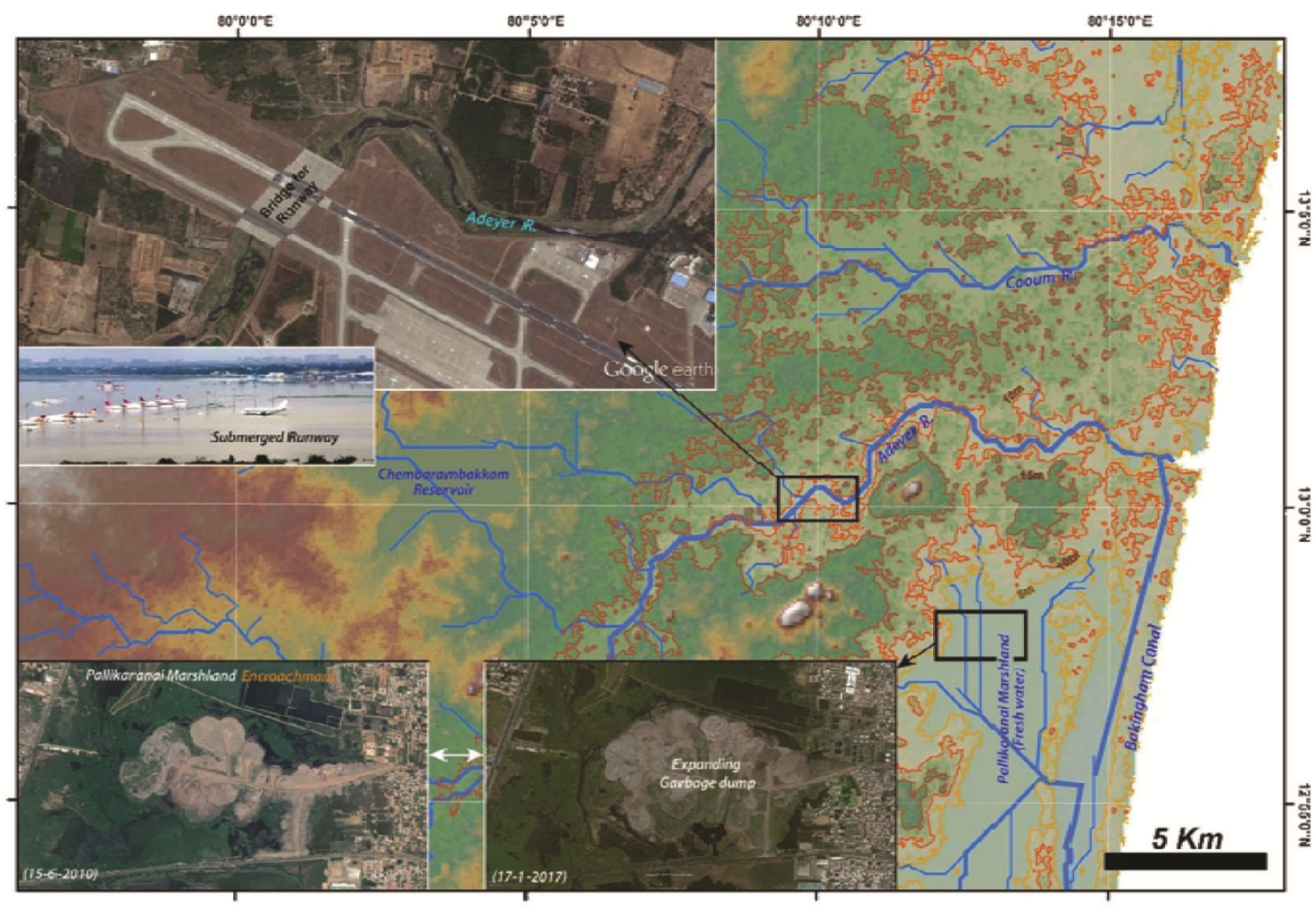

Figure 13. Digital elevation model of the coastal region around Chennai overlaid with the 5,10 and $15 \mathrm{~m}$ contours and drainage. Note that the inundated Chennai Airport is built on the pedimented flood plain of Adyar river with $<5 \mathrm{~m}$ relief and part of the runway is a bridge over the river. The encroachment of freshwater Pallikaranal marshland by toxic solid waste of the city not only reduced the buffer for flooding, but also contaminated the important source of groundwater recharge in the region.

surplus water from the Chembarambakkam reservoir, causing flooding along the river course. Prominent among the submerged regions is the extended runway of the Chennai International Airport (Figure 13, upper inset), where it crosses as an overbridge; the airport itself lies in the floodplain with a relief $\sim 5 \mathrm{~m}$ (Figure 13). Though extreme rainfall is bound to cause flooding, the problem is compounded by encroachment of floodways and poor planning of infrastructural growth.

There are about 162 small ponds and tanks in north Chennai to the north of Cooum river, 20 ponds and tanks in central Chennai between Cooum and Adyar rivers, and 17 to the south of Adayar river. These surface water bodies acted as major recharge structures for the depleting water table. Encroachment of catchment to reclaim land for infrastructural development and diversion of inlets, has led to the disappearance of most water tanks. The marshland and lagoon on either side of the Adyar Estuary have been transformed into built-up areas. The Pallikaranai freshwater marshland, which was a centre of biodiversity and important source for groundwater recharge, in addition to natural buffer for flood control by retaining excess surface run-off/flood water, is being reclaimed for infrastructure development by indiscriminate dumping of (toxic) solid waste (Figure 13, lower inset), thereby polluting and destroying the wetland even for groundwater recharge. The sand dunes and beach ridges have also been converted into residential areas, altering the natural landform. Only at a few places on the banks of Adayar river mouth, coastal morphology still exists.

The urbanization process caused increase in the run-off and reduction in the infiltration of water. It is observed that urban watersheds, on an average, lose $90 \%$ of the storm rainfall to run-off, whereas the non-urban forested watersheds retain $25 \%$ of the rainfall. Earlier an Expert Committee (1986) examined the reason for flooding other than rainfall, the effect of high tide and cyclonic storms on flood levels, including siltation and sand-bar formation at the river mouth and the effect of encroachments on the flood plain. The analysis concluded that the river's natural regime like flood plains, course, etc. should not be tampered with by human intervention. Flood-plain zoning and monitoring the future use must be prioritized. This recommendation seems to have been ignored. The drainage system, including man-made system in Chennai, continues to suffer due to lack of connectivity of storm sewers with macro-drainage and indiscriminate encroachments. The waterways are being blocked, leading to localized flooding and waterlogging conditions. 


\section{Disaster policy perspective}

The analysis of extreme rainfall events over the Indian subcontinent has important public policy implications for flood risk management in India.

The severity of a particular flood event is an outcome of a complex interplay of multiple factors, such as extreme rainfall in a short period, persistent rainfall over a long period, effect of the natural environment and effects of anthropogenic factors, particularly those relating to the built environment. In some cases - such as in the urban context - the cumulative effects of changes in the built environment may outweigh the effect of changes in rainfall pattern. It is important that all investments in the built environment - whether related to urban development or heavy transportation infrastructure - take into account the potential to escalate flood risk by increasing run-off or by disrupting the natural drainage. The impact of the built environment on hydrological regime and hydraulics is a subject of detailed examination.

Since the subject of the present article is primarily meteorological and geomorphological aspect of floods, we have discussed only those public policy implications that emanate directly from the findings described here, as opposed to wider issues of flood management-related public policy.

\section{Various approaches for issuing early warning for different types of floods}

Combinations of meteorological processes that lead to different kinds of floods - urban floods, mountain floods, riverine floods - are quite different. The effect of intensity, duration and persistence of rainfall is quite varied in different types of floods. In the urban context, this means that the approach to early warning, including its objectives and intended recipients will have to be quite different in different contexts.

- In the context of mountain floods, the expected lead time is likely to be small (2-4 h). A rainfall thresholdbased warning would represent the most practical approach. The main recipients of early warning would be the vulnerable communities that are directly affected. There is little time for emergency responders to respond and evacuate people. The main objective is protection of human lives.

- In the context of urban floods, the expected lead time is a little longer $(6 \mathrm{~h})$. For different rainfall thresholds, based on past events and on some modelling, inundation scenarios can be developed and location-specific warnings issued. The recipients of this warning would be communities, public utility companies, schools, hospitals and infrastructure operators.
- In the context of river floods, early warning with longer lead time is possible. The objective of early warning can go beyond saving lives to protecting livelihood. The recipients can range from communities to local administration to emergency response agencies at local, district, state and national levels.

\section{Greater application of intra-seasonal forecasts, particularly for riverine floods}

The analysis presented here indicates that our understanding of causes of variability within the season has improved. This knowledge should be integrated in the early warning systems for floods. Of course, a warning issued with 10-15 days lead time will have smaller confidence level, when integrated with short-range early warning. However, it could be valuable in taking advance action and prioritizing the deployment of disaster-response resources. Initially, this may be attempted on a pilot basis in some of the flood-prone areas. It can help us move towards multi-scalar - both spatial and temporal - early warning systems.

\section{Translating stream-flow forecasts into inundation forecasts}

For appropriate understanding and timely action, the stream-flow forecasts need to be translated into inundation forecasts. This has already been done for some parts of the country. Developing inundation forecasts requires flood modelling, which in turn requires good data on runoffs and digital elevation model of the terrain under study. Till all the flood-prone areas are covered by such modelling efforts, a community-based 'forecasting by analogy' effort may be undertaken in flood-prone areas. This means different stream-flow thresholds can be correlated with past episodes of flooding. This will at least provide an initial estimate of likely areas to be inundated at different stream-flow levels.

\section{Revising the flood-risk maps for the country}

As outlined earlier, in some parts of the country the number of intense rainfall events as well as the contribution of such events to seasonal rainfall have increased. These trends combined with the episodes of flooding in recent years in areas which are normally considered low-flood risk, indicate that the past is no longer going to be a good guide for the future. Rapid changes to our built environment will further alter the geography and nature of flood risk in the country. This means that flood-risk maps for India need to be revised. In addition, we need to institute a system by which flood-risk maps are revised every $5-10$ years. 


\section{Summary and conclusion}

It is amply clear from the above observations and discussion that the extreme climatic events are bound to produce excess surface run-off and flooding, but the response to them varies depending on the interaction of the affected habitat. Despite extreme rainfall and flooding, in the regions of the types discussed here, the effect of flooding varies due to local geomorphology and level of natural landscape encroachment. In the hilly region of Garhwal, rainfall produced enhanced surface run-off and affected only the lower level terraces along the higher gradient-confined meanders; the region is more prone to slope-related problems. The unique bowl-shaped low-relief geomorphology of Kashmir valley with restricted natural outlet is bound to suffer inundation during enhanced inflow during any extreme rainfall phenomenon. It may be noted here that Kashmir valley remained a large lake from $\sim 4$ ma until $\sim 85 \mathrm{ka}$ (ref. 56), and continues to remain a wetland due to the low relief along the valley axis. The rapid urbanization and indiscriminate encroachment of natural pathways of drainage is bound to cause clogging of surface run-off leading to spillover and flooding.

1. Berz, G. et al., World map of natural hazards - a global view of the distribution and intensity of significant exposures. Nat. Hazards, 2001, 23, 443-465; doi:10.1023/A:1011193724026.

2. Valdiya, K. S., Geology, Environment and Society, University Press, Hyderabad, 2004, p. 229.

3. Korup, O. and Clague, J. J., Natural hazards, extreme events, and mountain topography. Quaternary Sci. Rev., 2009, 28(11), 977-990.

4. Goswami, B. N., Venugopal, V. and Sengupta, D., Increasing trend of extreme rain events over India in a warming environment. Science, 2006, 314, 1442-1445

5. Rao, S. R., Dhakate, A. R., Saha, S. K., Mahapatra, S., Chaudhari, H. S., Pokhrel, S. and Sahu, S. K., Why is Indian Ocean warming consistently. Climate Change, 2012, 110, 709-719.

6. Roxy, M. K., Ritika, K., Terray, P., Murtugudde, R., Ashok, K. and Goswami, B. N., Drying of Indian subcontinent by rapid Indian Ocean warming and a weakening land-sea thermal gradient. Nature Commun., 2015, 6(7423), 1-10.

7. Gupta, A. K. and Nair, S. S., Urban floods in Bangalore and Chennai: risk management challenges and lessons for sustainable urban ecology. Curr. Sci., 2011, 100, 1638-1645.

8. Pai, D. S., Sridhar, L., Rajeevan, M., Sreejith, O. P., Satbhai, N. S. and Mukhopadhyay, B., Development of a new high spatial resolution $\left(0.25^{\circ} \times 0.25^{\circ}\right)$ long period $(1901-2010)$ daily gridded rainfall data set over India and its comparison with existing data sets over the region. MAUSAM, 2014, 65(1), 1-18.

9. Dhar, O. N. and Nandargi, S., Hydrometeorological aspects of floods in India. Nat. Hazards, 2003, 28, 1-33.

10. Sikka, D. R., Ray, K., Chakravarthy, K., Bhan, S. C. and Tyagi, A., Heavy rainfall in the Kedarnath valley of Uttarakhand during the advancing monsoon phase in June 2013. Curr. Sci., 2015, 109(2), 2353-2361.

11. Chevuturi, A. and Dimri, A. P., Investigation of Uttarakhand (India) disaster-2013 using weather research and forecasting model. Nat. Hazards, 2016, 82(3), 1703-1726.

12. Pattanaik, D. R. and Rajeevan, M., Variability of extreme rainfall events over India during southwest monsoon season. Meteorol. Appl., 2010, 17(1), 88-104.
13. Niyas, N. T., Srivastava, A. K. and Hatwar, H. R., Variability and trend in the cyclonic storms over north Indian Ocean. Meteorological Monograph No. 3 Cyclone Warning-3/2009, 2009.

14. Karuna, S. S., Rajeevan, M. and Rao, S. V. B., On increasing monsoon rainstorms over India. Nature Hazards, 2016 , doi:10.1007/s11069-016-2662-9.

15. Sen Roy, S. and Balling Jr, R. C., Trends in extreme daily precipitation indices in India. J. Climate, 2004, 24(4), 457-466.

16. Rakhecha, P. R. and Soman, M. K., Trends in the annual extreme rainfall events of 1 to 3 days duration over India. Theoret. Appl. Climatol., 1994, 48(4), 227-237.

17. Ramaswamy, C., Meteorological aspects of severe floods in India 1923-1979. Meteorological Monograph Hydrology No. 10/1987, India Meteorological Department (IMD), New Delhi, 1987.

18. Dhar, O. N. and Nandargi, S. S., The zones of severe rainstorm activity over India. Int. J. Climatol., 1993, 13(3), 301-305.

19. De, U. S., Singh, G. P. and Rase, D. M., Urban flooding in recent decades in four mega cities of India. J. Indian Geophys. Union, 2013, 17(2), 153-165

20. Jenamani, R. K., Bhan, S. C. and Kalsi, S. R., Observational/forecasting aspects of the meteorological event that caused a record highest rainfall in Mumbai. Curr. Sci., 2006, 90, 13441362 .

21. Lal, B., Jayanthi, N., Thakur Prasad, Rajeevan, M., Sunitha Devi, Srivastava, A. K. and Pai, D. S., Monsoon 2005, A Report, National Climate Centre, Indian Meteorological Department, Pune, 2006, pp. 42-57.

22. Shyamala, B. and Bhadram, C. V. V., Impact of mesoscalesynoptic scale interactions on the Mumbai historical rain event during 26-27 July 2005. Curr. Sci., 2006, 12, 1649-1654.

23. Vaidya, S. S. and Kulkarni, D. R., Simulation of heavy precipitation over Santacruz Mumbai on 26 July 2005 using Mesoscale model. Meteorol. Atmos. Phys., 2007, 98, 55-56.

24. Mohapatra, M., Kumar, N. and Bandyopadhyay, B. K., Role of mesoscale low and urbanization on exceptionally heavy rainfall event of 26 July 2005 over Mumbai: some observational evidences. MAUSAM, 2009, 60(3), 317-324.

25. Rao, Y. P., Southwest Monsoon, Meteorological Monograph. Synoptic Meteorology IMD, Pune, 1976, p. 367.

26. Mooley, D. A., The role of western disturbances in the production of weather over India during different seasons. Indian J. Metero. Geophys., 1957, 8, 253-260.

27. Dimri, A. P., Niyogi, D., Barros, A. P., Ridley, J., Mohanty, U. C., Yasunari, T. and Sikka, D. R., Western disturbance: a review. Rev. Geophys., 2015, 53(2), 225-246; http://dx.doi.org/10.1002/ 2014RG000460.

28. Sikka, D. R., Synoptic and mesoscale weather disturbances over south Asia during the southwest summer monsoon season. In The Global Monsoon System: Research Forecast (Chang, C. P. et al.), World Scientific, New Jersey, USA, 2011, 2nd edn, pp. 183-204.

29. Yadav, B. P., Khole, M. and Kumar, N., Unusual weather over northwest and west India during, November 2010. MAUSAM, 2013, 64(4), 699-710.

30. Dobhal, D. P., Gupta, A. K., Mehta, M. and Khandelwal, D. D., Kedarnath disaster: facts and plausible causes. Curr. Sci., 2013, 105(2), 171-174.

31. Dimri, A. P. et al., Cloudburst in Indian Himalayas: a review. Earth-Sci. Rev., 2017, 168, 1-23.

32. Houze Jr, R. A., Rasmussen, K. L., Medina, S., Brodzik, S. R. and Romatschke, U., Anomalous atmospheric events leading to the summer 2010 floods in Pakistan. Bull. Am. Meteorol. Soc., 2011, 92, 291-298; doi:10.1175/2010BAMS3173.1.

33. Medina, S., Houze Jr, R. A., Kumar, A. and Niyogi, D., Summer monsoon convection in the Himalayan region: terrain and land cover effects. Q. J. R. Meteorol. Soc., 2010, 136(648), 593-616.

34. Ananthakrishnan, R. and Bhatia, K. L., Tracks of monsoon depressions and their recurvature towards Kashmir. Monsoon of 


\section{REVIEW ARTICLES}

the World. India Meteorological Department, New Delhi, 1960 pp. $157-172$.

35. Ghosh, S. K. and Veeraraghavan, K., Severe floods in Jammu and Kashmir in August 1973. Indian J. Meterol. Hydrol. Geophys., 1975, 26(2), 203-207.

36. Ray, K., Bhan, S. C. and Bandopadhyay, B. K., The catastrophe over Jammu and Kashmir in September 2014: a meteorological observational analysis. Curr. Sci., 2015, 109(3), 580-591.

37. Das, P. K., The Monsoon, National Book Trust of India, New Delhi, 1995, pp. 143-160.

38. Sengupta, S., Localised floods in Rajasthan owing to exceedingly heavy rains: case study of small scale accentuations in the Indian summer monsoon fields associated with intense upper anticyclonic shear zones. MAUSAM, 1986, 37(3), 385-390.

39. Ray, K., Mohanty, M. and Chincholikar, J. R., Climate variability over Gujarat, India. In ISPRS Archives XXXVIII-8/W3, Workshop Proceedings: Impact of Climate Change on Agriculture, Space Applications Centre (ISRO), Ahmedabad, 2009, pp. 38-43.

40. Mohanty, M., Ray, K. and Chakravarthy, K., Analysis of increasing heavy rainfall activity over western India, particularly Gujarat State in the past decade. In High-Impact Weather Events over the SAARC Region (eds Ray et al.), Springer, Cham, 2015; doi:10.1007/978-3-319-10217-7_17.

41. Rajeevan, M., Unnikrishnan, C. K., Bhate, J., Kumar, N. and Sreekala, P. P., Northeast monsoon over India: variability and prediction. Meteorol. Appl., 2012, 19, 226-236.

42. Krishnamurti, T. N., Jha, B., Rasch, P. J. and Ramanathan, V., High resolution global reanalysis highlighting the winter monsoon - Part I: reanalysis field. Meteorol. Atmos. Phys., 1997, 64, $123-150$.

43. Krishnamurti, T. N., Jha, B., Rasch, P. J. and Ramanathan, V., High resolution global reanalysis highlighting the winter monsoon-Part II: transients and passive tracer transport. Meteorol. Atmos. Phys., 1997, 64, 151-171.

44. Krishnamurti, T. N., Tewari, N., Rajendran, K. and Gadgil, S., A heavy winter monsoon rainfall episode influenced by easterly waves, a westerly trough, blocking and the ITCZ. Weather, 2002, 57, 367-370.

45. Kripalani, R. H. and Kumar, P., Northeast monsoon rainfall variability over south peninsular India vis-à-vis Indian Ocean dipole mode. Int. J. Climatol., 2004, 24, 1267-1282.

46. Kamalji, R., Kannan, B. A. M., Stella, S., Sen, B., Sharma, P. and Thampi, S. B., Heavy rains over Chennai and surrounding areas as captured by Doppler weather radar during Northeast Monsoon 2015: a case study. In Remote Sensing of the Atmosphere, Clouds and Precipitation VI, International Society for Optics and Photon- ics, 2016, vol. 9876, p. 98762G; http://dx.doi.org/10.1117/12. 2239563.

47. Valdiya, K. S., Damming rivers in the tectonically resurgent Uttarakhand Himalaya. Curr. Sci., 2014, 106(12), 16581668.

48. Rana, N., Singh, S., Sundriyal, Y. P. and Juyal, N., Recent and past floods in the Alaknanda valley: causes and consequences. Curr. Sci., 2013, 105(9), 1209-1212.

49. Jones, E. J., Notes on the Kashmir earthquake of 30 May 1885. Rec. Geol. Surv. India, 1885, 18, 153-156.

50. Bilham, R. and Bali, B S., A ninth century earthquake-induced landslide and flood in the Kashmir Valley, and earthquake damage to Kashmir's medieval temples. Bull. Earthq. Eng., 2013, 11, 1-31.

51. Bhatt, C. M. et al., Satellite-based assessment of the catastrophic Jhelum floods of September 2014, Jammu and Kashmir, India. Geomat. Nat. Haz. Risk, 2016; doi:10.1080/19475705. 2016.1218943.

52. Farooq, M. and Muslim, M., Dynamics and forecasting of population growth and urban expansion in Srinagar city - a geospatial approach. Int. Arch. Photogramm., Remote Sensing Spat. Inf. Sci., 2014, XL-8, 709.

53. Meraj, G., Romshoo, S. A., Yousuf, A. R., Altaf, S. and Altaf, F., Assessing the influence of watershed characteristics on the flood vulnerability of Jhelum basin in Kashmir Himalaya. Nat. Haz., 2015, 77, 153-175; doi:10.1007/s11069-015-1605-1.

54. Joshi, P. K., Rashid, H. and Roy, P. S., Landscape dynamics in Hokersar wetland, Jammu and Kashmir - an application of geospatial approach. J. Indian Soc. Remote Sensing, 2002, 30, 1-5.

55. Romshoo, S. A., Ali, N. and Rashid, I., Geoinformatics for characterizing and understanding the spatio-temporal dynamics (1969 to 2008) of Hokersar wetland in Kashmir Himalayas. Int. J. Phys. Sci., 2011, 6, 1026-1038; doi:10.5897/IJPS10.378.

56. Dar, R. A., Romshoo, S. A., Chandra, R. and Ahmad, I., Tectonogeomorphic study of the Karewa Basin of Kashmir Valley. J. Asian Earth Sci., 2014, 92, 143-156.

ACKNOWLEDGEMENTS. We thank National Mission on Himalayan Studies, Ministry of Environment, Forest and Climate Change and Mahalanobis National Crop Forecast Centre for support, and Dr A. K. Pandey (NGRI, Hyderabad), for useful discussions.

Received 1 January 2018; revised accepted 19 March 2019

doi: $10.18520 / \mathrm{cs} / \mathrm{v} 117 / \mathrm{i} 2 / 204-218$ 